\title{
Approach of monocarpic senescence control by nitrogen manipulation in mungbean and cowpea
}

\author{
$\bowtie$ Md. Matiul Islam ${ }^{1,2}$, Seijun Sakamoto ${ }^{3}$ and Shao-Hui Zheng ${ }^{3}$
}

${ }^{\mathbf{1}}$ The United Graduate School of Agricultural Sciences, Kagoshima University, Kagoshima 890-0065, Japan; ${ }^{2}$ Agrotechnology Discipline, Khulna University, Khulna 9208, Bangladesh and ${ }^{3}$ Tropical Crop Improvement Laboratory, Faculty of Agriculture, Saga University, Saga 840-8502, Japan

\begin{tabular}{|c|c|}
\hline ARTICLE INFO & Abstract \\
\hline $\begin{array}{l}\text { Article history: } \\
\text { Received: } 26 \text { July } 2018 \\
\text { Accepted: 04 December } 2018 \\
\text { Published: } 31 \text { December } 2018\end{array}$ & \multirow{3}{*}{$\begin{array}{l}\text { Pods start growing almost at the same time and mature simultaneously in soybean (Glycine max (L.) } \\
\text { Merrill) plants. But mungbean (Vigna radiata L. Wilczek) and cowpea (Vigna sinensis Endl.) perform } \\
\text { unsynchronized pod maturity. To overcome unsynchronized pod maturity the nitrogen redistribution } \\
\text { aspects of mungbean and cowpea were investigated based on the linkage of soybean. Pot experiment was } \\
\text { conducted using a nodulating mungbean variety ( } \mathrm{cv} \text {. XANH NINH THUAN) in } 2015 \text { and cowpea variety } \\
(\mathrm{cv} \text {. IT98K-205-8) in } 2016 \text { in the vinyl house at Saga University in Japan. During the experiment, nutrient } \\
\text { solution was applied by changing nitrogen concentrations to } 5,25 \text { and } 100 \text { ppm (control). Mungbean } \\
\text { plants provided with low concentration of } 5 \text { and } 25 \text { ppm of nitrogen supply was not capable to produce } \\
\text { continuous pods. Cowpea plants supplied with low concentration of nitrogen was also unable to produce } \\
\text { successful pods continuously. Insufficient nitrogen hampered the continuation of pod setting in both the } \\
\text { cases, might be due to, all the vegetative stored nitrogen had been utilized for seed development during the } \\
\text { vegetative phase before pod setting. In case of } 100 \text { ppm nitrogen supply, for both mungbean and cowpea, } \\
\text { no senescence and nitrogen remobilization occurred. However, researches showed that soybean typically } \\
\text { undergoes the remobilization evidence, i.e., monocarpic senescence, in } 100 \text { ppm of nitrogen supply. }\end{array}$} \\
\hline $\begin{array}{l}\text { Keywords: } \\
\text { Mungbean; Cowpea; Nitrogen, } \\
\text { Nitrogen remobilization; Soybean }\end{array}$ & \\
\hline $\begin{array}{l}\text { Correspondence: } \\
\text { Dr. Md. Matiul Islam } \\
\bigotimes: \text { matiul_rubel@yahoo.com }\end{array}$ & \\
\hline
\end{tabular}

(C)2018 by authors and BAURES. This work is licensed under the Creative Commons Attribution International License (CC By 4.0).

\section{Introduction}

Soybean [Glycine $\max$ (L.) Merrill] plants express monocarpic senescence. Accompanying the pod maturation, the leaves and petioles tend to yellow, and abscise, and the whole plant wilts. This habit is very helpful for the farmers to harvest the crop by harvester machine, making soybean production easy. However, in most of leguminous species, such as mungbean (Vigna radiata L. Wilczek), cowpea (Vigna sinensis Endl.), etc., it is visually observed that the leaf and stem keep green even at harvest time.

Mungbean and cowpea are widely grown pulse crops in the tropics and subtropics. Mungbean originally comes from Southeast Asia and India. This crop is characterized by producing protein-rich seeds with good taste. Mungbean is a popular and important crop in the Southeastern Asia, because of its high content of easily digestible protein and wide adaptability for cultivation (Poehlman, 1991). This legume, as a short-duration crop in various cropping system, increases tenant farmers' income and improves soil fertility (Tomooka et al., 1991). Mungbeans are grown widely for the uses as not only human food (as dry beans or fresh sprouts), but also a green manure crop and forage for livestock. Mungbean is an important legume in tropical regions, which is intercropped with other crops such as cereals. However, its low productivity, low seed yield and unsynchronized pod maturity are considered to limit the production area.
Besides mungbean, the cowpea is one of the most important food legume crops in the semiarid tropics. A drought-tolerant and warm-weather crop, cowpeas are well-adapted to the drier regions of the tropics, where other food legumes do not perform well. It also has useful ability to fix atmospheric nitrogen through its root nodules. In addition, it is shade tolerant, so is compatible as an intercrop. The leaves of the cowpea plant have the highest percentage of calories from protein among vegetarian foods (Rangel et al., 2003). Cowpeas provide a rich source of proteins and calories, as well as minerals and vitamins. A cowpea seed can consist of $25 \%$ protein and is low in anti-nutritional factors (Rangel et al., 2003).

In mungbean and cowpea, flowering and fruiting concurrently occur over a long period. However, the pod growth starts immediately after the first flower opened, and matured even during flowering period. Therefore, the matured pods, young pods and even flowers appear on the plant at thesame time. For these characteristics of mungbean and cowpea, it is difficult to decide harvesting time. Generally, harvest time starts when one half to two-third of the pods matured. In the developing countries, the matured pods are handpicked up at harvest. Usually, mungbean and cowpea production has this harvesting problem in Asia (especially in the developing countries), and the farmers spend much time in harvesting. It causes difficulty to extend the 
mungbean and cowpea production widely. The seed yield of leguminous crops is determined by the number of seeds per unit area and individual seed weight. The seed number depends upon the number of flowers that initiate pods and attain to maturity. The seed yield in soybean has been increasing and reached to about 2.2 ton per hectare in the world, whereas only about 1 ton per hectare in mungbean and cowpea (Islam, 2017).

In contrast with these two beans, soybean plants open the flowers also for a long period, whereas the pods start growing almost at the same time and mature simultaneously (Zheng et al., 2003). It is revealed that the soybean plants accumulate nitrogen in the vegetative parts and when the seed development commences at R6 stage (i.e., full seed stage) the accumulated nitrogen starts to remobilize to the seeds, because directly assimilated nitrogen cannot fulfill the seed requirement (Islam et al., 2016). Thus soybean plant undergoes synchronized pod maturation and commits monocarpic senescence. It is also revealed that the nitrogen manipulation affects the leaf senescence i.e., high concentration of nitrogen supply can stop the soybean leaf senescence (Islam et al., 2016). During the process of senescence the autophagy gene, GmATG8c, becomes activated and high concentration of nitrogen supply can affect the activation of GmATG8c (Islam et al., 2017). The specific objective of this study was to compare the soybean leaf senescence with mungbean and cowpea so that a clear image of nitrogen redistribution and some of its related aspects could be depicted.

\section{Materials and Methods}

To compare the soybean leaf senescence with mungbean and cowpea, pot experiment was conducted using mungbean variety ( $c v$. XANH NINH THUAN) in a sideopened vinyl house in Saga University, Japan $\left(33^{\circ} 14^{\prime} 32^{\prime \prime} \mathrm{N}\right.$ and $\left.130^{\circ} 17^{\prime} 28^{\prime \prime} \mathrm{E}\right)$. The plants were grown during 27 July to 9 November 2015. Another pot experiment was conducted using cowpea variety $(c v$. IT98K-205-8) in the same vinyl house. The cowpea plants were grown during 22 September to 9 November 2016. In both the years, the procedures and conditions were the same for the production process of mungbean and cowpea. In both the cases soybean were grown together (in 2015 along with mungbean; and in 2016 along with cowpea). The soybean monocarpic senescence related experimental methods and results have been discussed in Islam et al., 2016 and Islam et al., 2017. Four seeds were sown in the pots $(16 \mathrm{~cm}$ diameter and $20 \mathrm{~cm}$ depth) filled with well washed fine sand and vermiculite (1:1), and then the seedlings were thinned to one plant per pot when the trifoliate leaf extended fully. The seeds were inoculated with Bradyrhizobium Spp. (Konryukin Mame-zo, Tokachi Nokyoren, Hokkaido, Japan). After emergence, all the plants were watered twice a week with a half concentration (50 ppm nitrogen) of the basic nutrient solution following the research conducted by Zhao et al. (2014b) (Table 1), and then with full concentration of the basic solution (100 ppm nitrogen) from two weeks after emergence till harvest.

The nitrogen concentration in the basic nutrient solution was changed after two weeks of sowing. During experiment, nutrient solution was applied by changing nitrogen concentrations to 5, 25 and $100 \mathrm{ppm}$ (control). Nutrient solutions were applied twice a week with enough amounts $\left(\approx 1000 \mathrm{ml} \mathrm{pot}^{-1}\right)$ which could replace the previous residual solution in the sand-vermiculite medium, while plain water was supplied to make the medium moistened enough in the interval period based on the observed dryness of the sand-vermiculite medium. Five plants were used in each treatment.

Table 1. Reagents and concentrations of nutrient solution. (Zhao et al., 2014b)

\begin{tabular}{ccll}
\hline Nutrient & Concentration (ppm) & Reagents \\
\hline $\mathrm{N}$ & 5,25, & & $\mathrm{NH}_{4} \mathrm{NO}_{3}$ \\
& 100 & & \\
$\mathrm{P}$ & 70 & $\mathrm{KH}_{2} \mathrm{PO}_{4}$ \\
$\mathrm{~K}$ & 110 & $\mathrm{~K}_{2} \mathrm{SO}_{4}, \mathrm{KH}_{2} \mathrm{PO}_{4}$ \\
$\mathrm{Mg}$ & 90 & & $\mathrm{Mg} \mathrm{SO}_{4}$ \\
$\mathrm{Ca}$ & 35 & & $\mathrm{CaCl}_{2}$ \\
$\mathrm{Fe}$ & 3 & .5 & $\mathrm{NaFeEDTA}$ \\
$\mathrm{Mn}$ & 0 & .3 & $\mathrm{MnSO}_{4}$ \\
$\mathrm{~B}$ & 0 & .06 & $\mathrm{H}_{3} \mathrm{BO}_{3}$ \\
$\mathrm{Zn}$ & 0 & .009 & $\mathrm{ZnSO}_{4}$ \\
$\mathrm{Cu}$ & 0 & .009 & $\mathrm{CuSO}_{4}$ \\
$\mathrm{Mo}$ & 0 & .009 & $\mathrm{MoO}_{3}$ \\
\hline
\end{tabular}

Modified from Matsunaga et al. (1983)

After starting the treatment, two leaf discs $\left(2.54 \mathrm{~cm}^{2}\right.$, each) were collected from the leaflet on $2^{\text {nd }}$ to $3^{\text {rd }}$ leaves from the top on the main stem with two to six days interval and dried in an air-circulating oven at $70^{\circ} \mathrm{C}$ for 48 hours for nitrogen quantification by Kjeldahl method (Jackson, 1973). Two leaf discs $\left(2.54 \mathrm{~cm}^{2}\right.$, each) were also taken from the same plants with three to eight days interval and freezed immediately by using liquid nitrogen $\left(-196^{\circ} \mathrm{C}\right)$, and stored in a deep freezer (at $-80^{\circ} \mathrm{C}$ ) for soluble protein quantification by Bradford method (Bradford, 1976).

The leaf photosynthetic rates were measured by three to seven days interval with portable photosynthesis system LI-6400 (LI-COR Bioscience, Lincoln NE, USA), on the sunny day between 10.00 to 12.00 A.M. using the leaflet on $2^{\text {nd }}$ to $3^{\text {rd }}$ leaves, from the top on the main stem. The conditions set for photosynthesis measurement were: leaf temperature $30^{\circ} \mathrm{C}$, reference $\mathrm{CO}_{2} 370 \mathrm{ppm}$ and photosynthetically active radiation (PAR) $1500 \mu \mathrm{mol}$ photons $\mathrm{m}^{-2} \mathrm{~s}^{-1}$. Leaf SPAD values (the term and value used to express greenness of plant leaves), an indicator of chlorophyll content, were measured with SPAD meter (SPAD-502, Minolta Co. Ltd., Japan) with three to six days interval. At the harvest maturity stage, all the plants in each treatment were harvested for the determination of the seed yield and yield components. 
Single factor analysis of variance (ANOVA) method and Tukey's HSD (along with lettering) were used for the analysis of significance (at $5 \%$ level, i.e., $p<0.05$ ) on all the parameters among the different treatments. MS Excel and Statistical Package for Social Sciences (SPSS) were used for analyzing the data and related graph preparation.

\section{Results}

\section{Mungbean}

Mungbean plants started to produce flowers and pods at around four weeks after emergence. There were flowers, immature pods and mature pods on the same plant at around 6 weeks after emergence. Mature pods were harvested from 10 days after treatment (DAT). The leaves provided with low concentration (5 and $25 \mathrm{ppm}$ ) of nitrogen supply started yellowing at 20 DAT.
However, the control plants $(100 \mathrm{ppm})$ were green at that time (Photo 1). In Fig. 1, it is observed that the plants provided with low concentration of nitrogen supply showed lower leaf SPAD values than the control and the leaf SPAD values started to decrease after 8 DAT. However, the control plants maintained steadily higher leaf SPAD values and it was significantly higher $(p<0.05)$ than the lower concentration of nitrogen supply except at 2 and 8 DAT. Similarly, in Fig. 2, the photosynthetic rates were rapidly lower for the lower concentration of nitrogen supply. The control concentration of nitrogen supply maintained significantly higher $(p<0.05)$ rate of photosynthesis than the 5 and $25 \mathrm{ppm}$ treatments except at $2 \mathrm{DAT}$. This trend was steadily maintained during the entire treatment period.

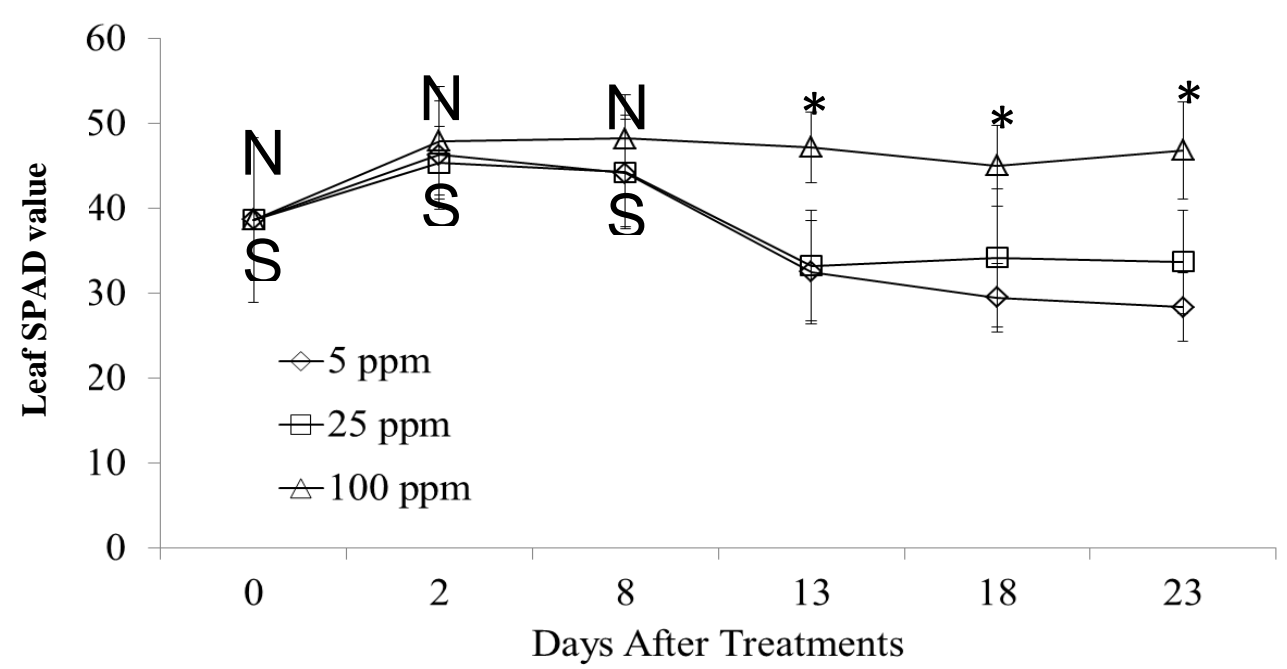

Fig. 1. Changes in leaf-SPAD values in Mungbean in 2015 with different treatments during reproductive growth. Bars indicate the standard deviations with three replications. ${ }^{*} p<0.05$,

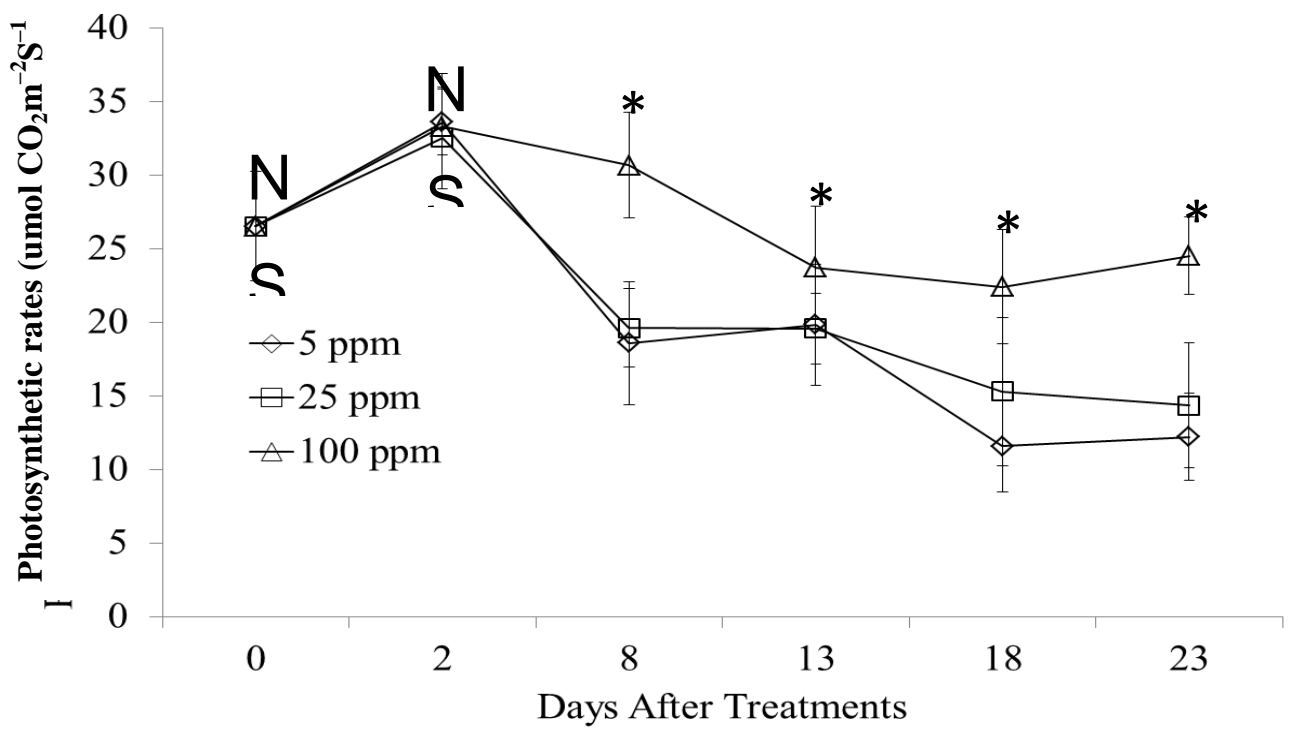

Fig. 2. Leaf photosynthetic rates in Mungbean in 2015 with different treatments during reproductive growth. Bars indicate the standard deviations with three replications. * $p<0.05$, NS- not significant 
In case of leaf nitrogen concentration (Fig. 3), it was observed that the lower concentration of nitrogen supply always rendered lower leaf nitrogen concentration than the control plants during experiment. The nitrogen concentration was significantly different $(p<0.05)$ between control and the lower concentration of nitrogen supply at every sampling dates after starting the experiment. The leaf soluble protein concentration started to decrease at 8 DAT in all treatments, however, the control plant always produced significantly higher $(p<0.05)$ leaf soluble protein concentration than the plants in lower concentration of treatments (Fig. 4).

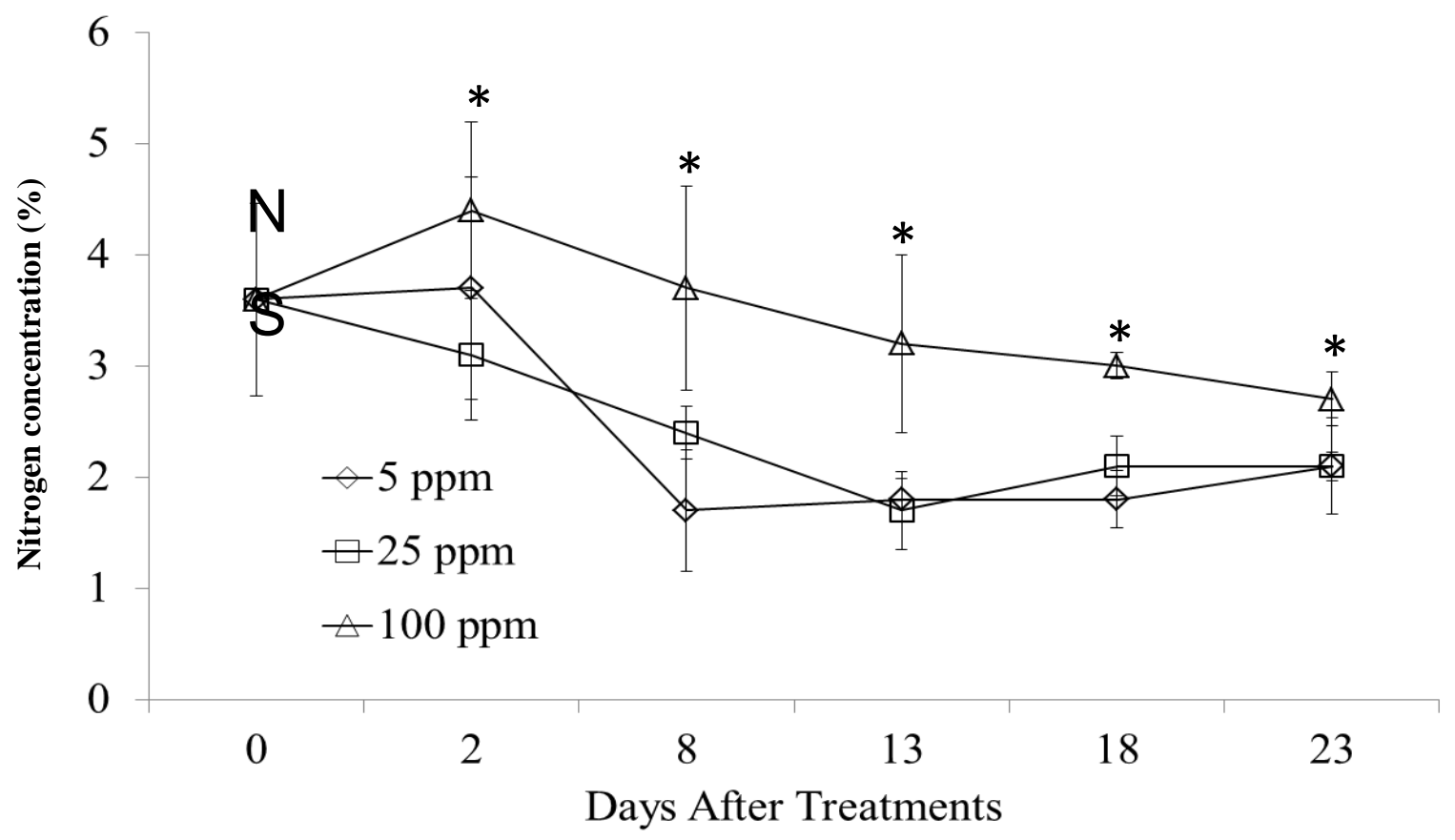

Fig. 3. Changes in leaf nitrogen concentration in Mungbean in 2015 with different treatments during reproductive growth. Bars indicate the standard deviations with three replications. $* p<0.05$, NS- not significant

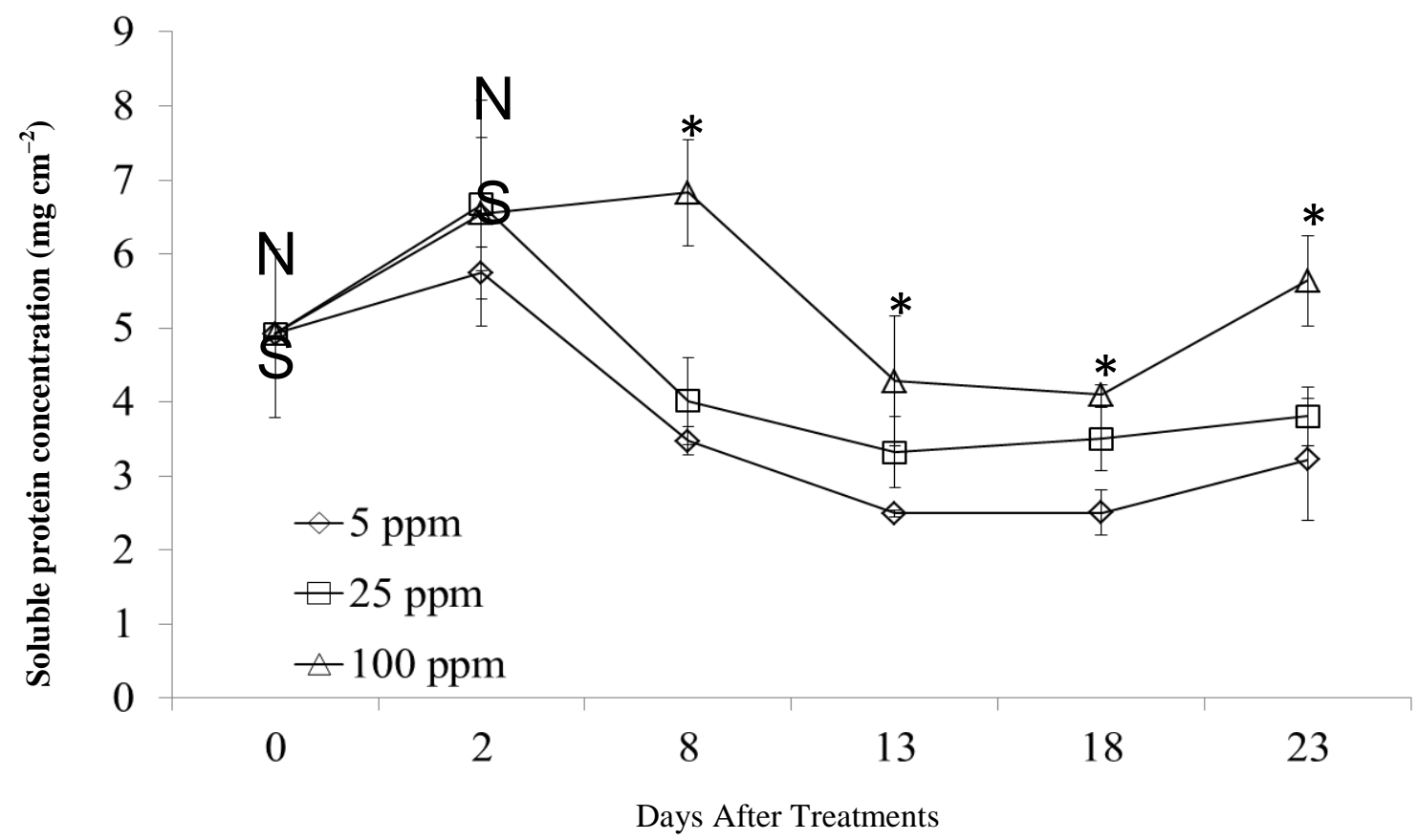

Fig. 4. Changes in soluble leaf protein concentration in Mungbean in 2015 with different treatments during reproductive growth. Bars indicate the standard deviations with three replications. * $p<0.05$, NS- not significant. 


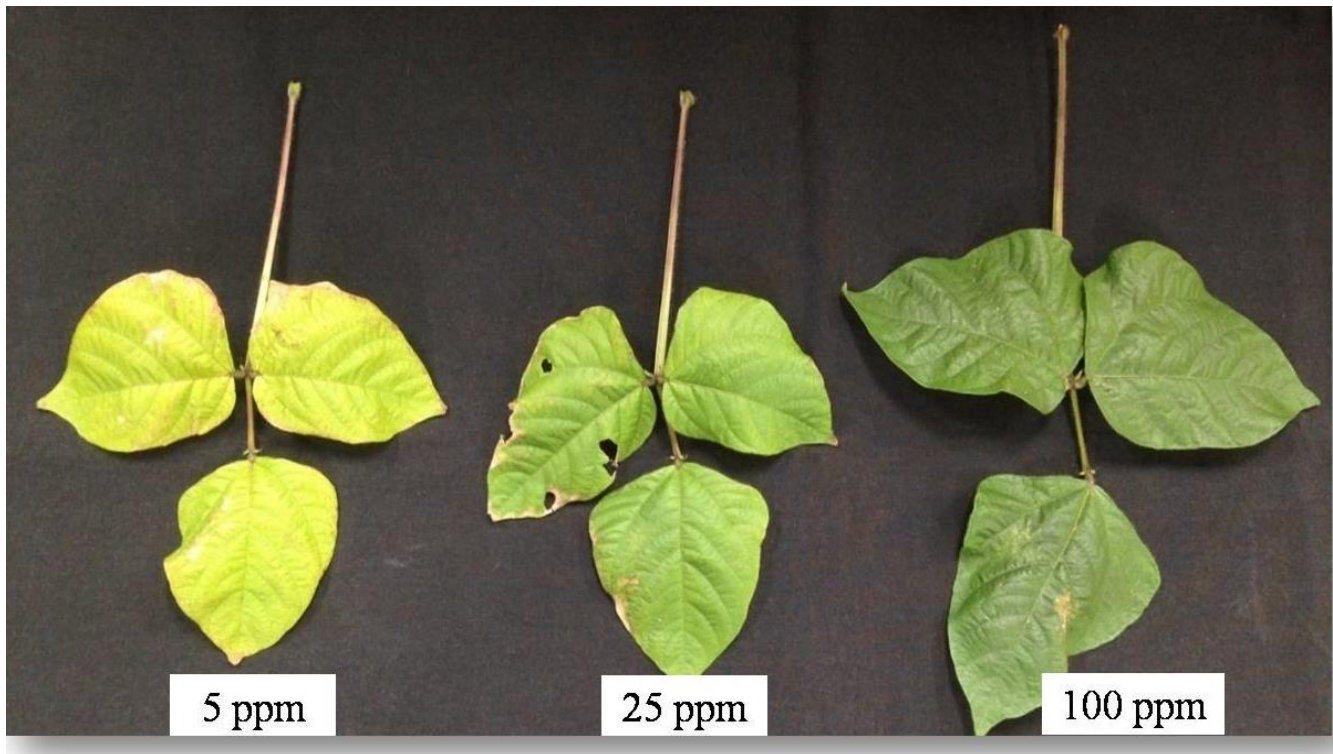

Photo 1. Plants with low concentration of nitrogen supply rendered the leaves to become yellow in Mungbean in 2015.

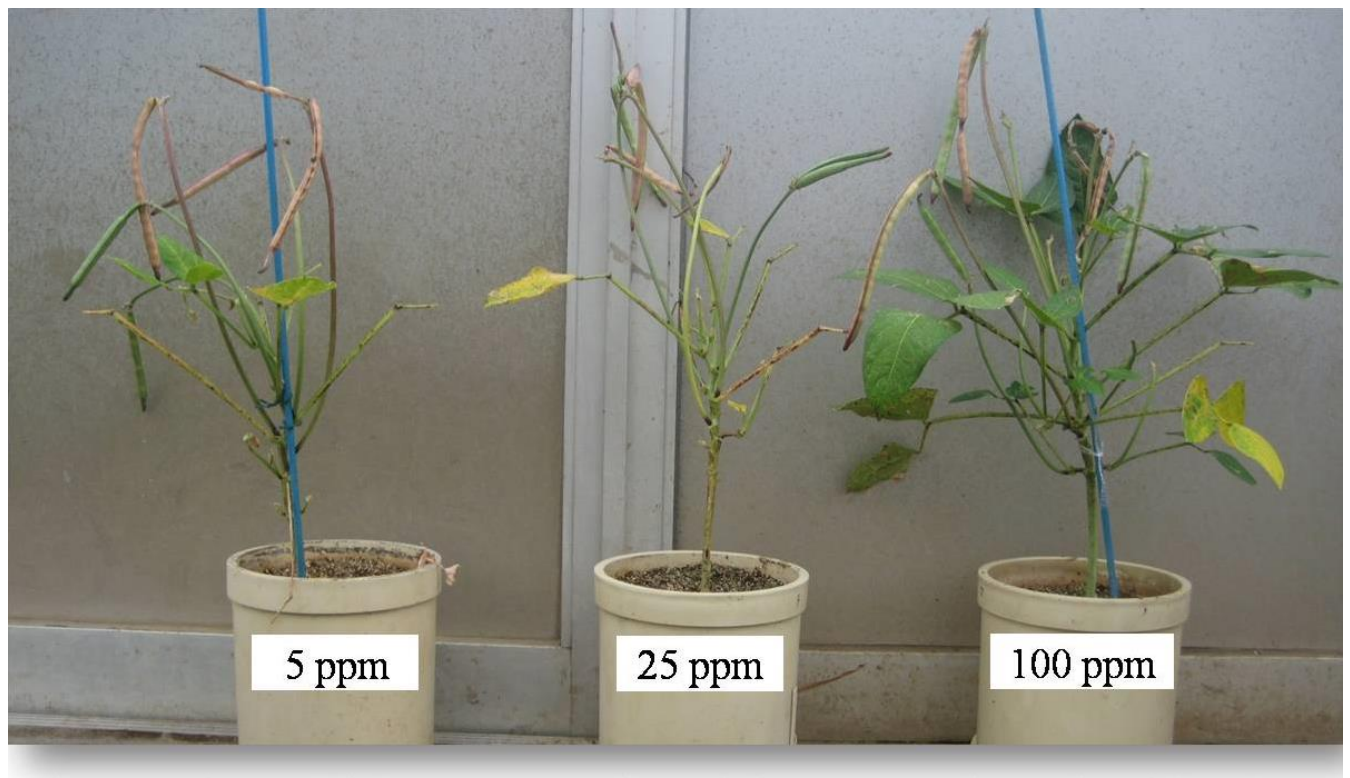

Photo 2. Plants with low concentration of nitrogen supply rendered the plants to become yellow in Cowpea in 2016.

\section{Cowpea}

Plants provided with $100 \mathrm{ppm}$ of nitrogen didn't undergo leaf senescence. There were flowers, immature pods and mature pods on the same plant, and pod setting was observed as a continuous process. Plants provided with low concentration of nitrogen supply rendered the leaves to become yellow during pod development (Photo 2). The leaf SPAD values decreased till $18 \mathrm{DAT}$, but the $100 \mathrm{ppm}$ nitrogen treatment maintained green leaves avoiding senescence (Fig. 5) and significantly differed from the 5 and 25 ppm concentration of nitrogen supply at 11 DAT and onward. Similarly the photosynthetic rates decreased in all treatments till $14 \mathrm{DAT}$, and then started to increase in $100 \mathrm{ppm}$ treatment at $18 \mathrm{DAT}$ as some new pods appear. Leaf photosynthetic rates in control treatment $(100 \mathrm{ppm})$ significantly differed from other treatments at 7 DAT and onward (Fig. 6). Similar results were also found in the case of nitrogen concentration in the leaves (Fig. 7). The control treatment significantly differed from the other treatments at 3 DAT and onward except at 11 DAT in case of nitrogen concentration in the leaves. Similar trend was also observed in leaf soluble protein concentration (Fig. 8 ), where the control treatment maintained significantly higher concentration of leaf soluble protein at 3 DAT and onward. 


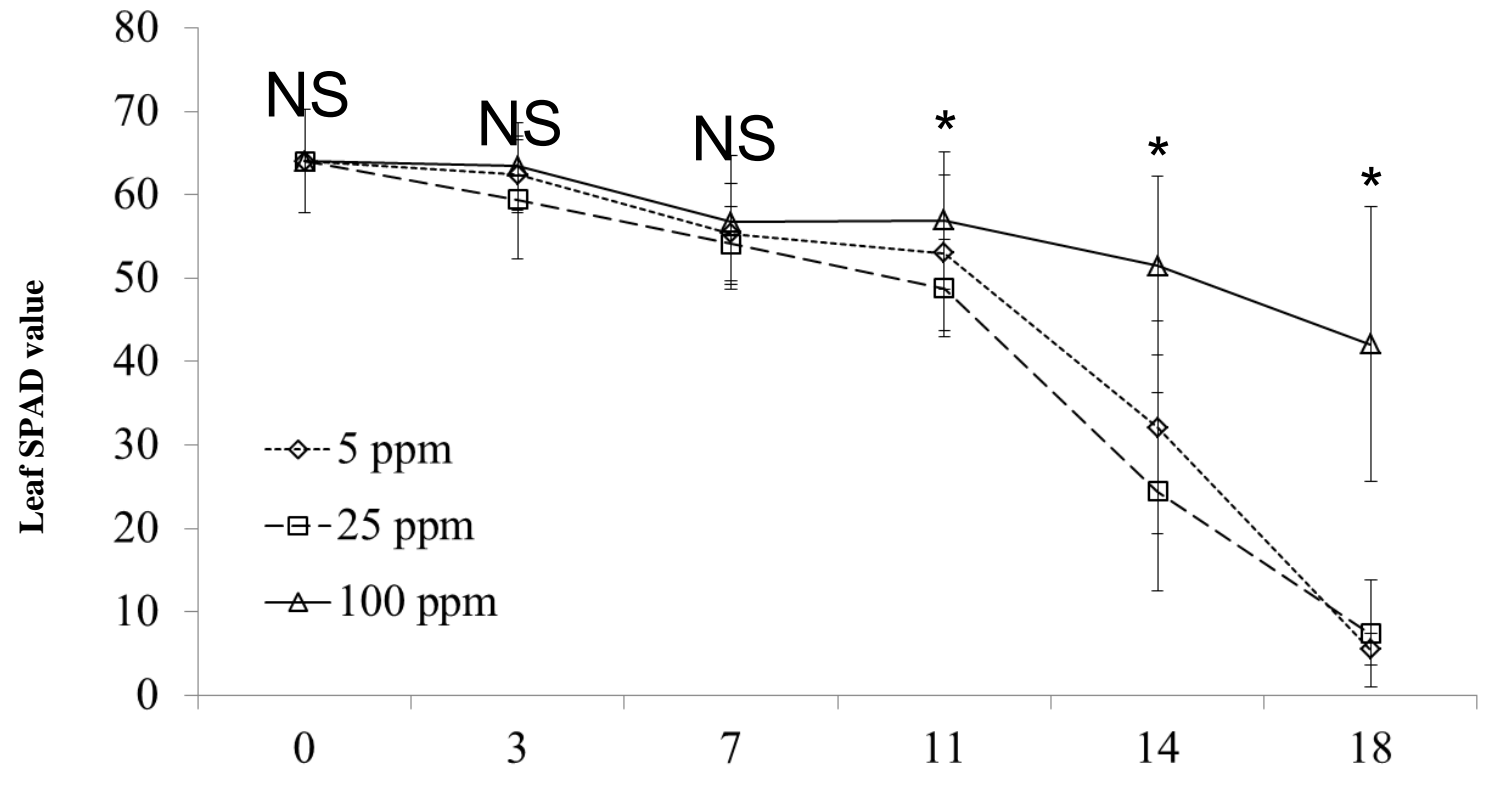

\section{Days After Treatments}

Fig. 5. Changes in leaf-SPAD values in Cowpea in 2016 with different treatments during reproductive growth. Bars indicate the standard deviations with three replications. ${ }^{*} p<0.05$, NS- not significant.

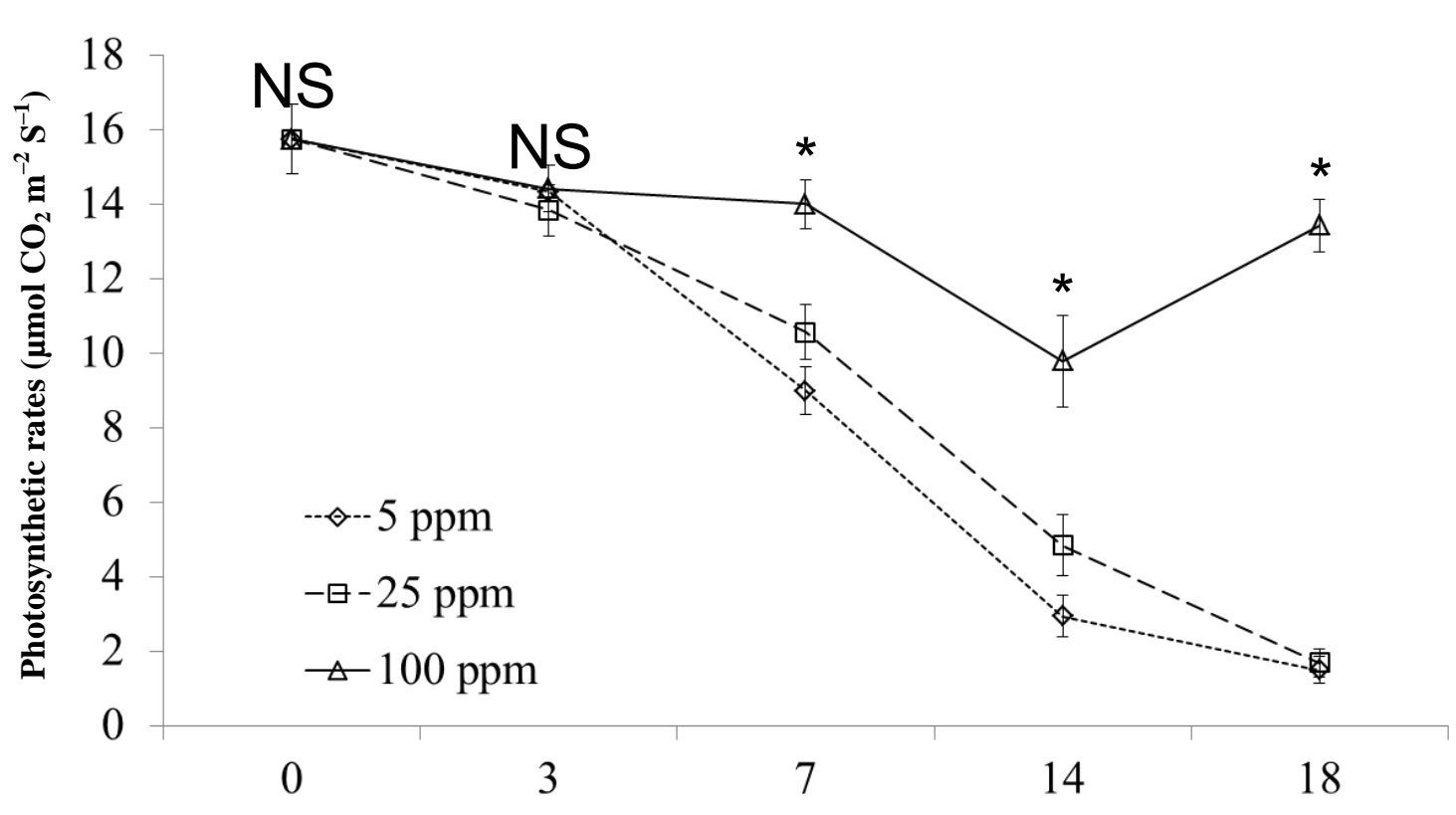

Days After Treatments

Fig. 6. Leaf photosynthetic rates in Cowpea in 2016 with different treatments during reproductive growth. Bars indicate the standard deviations with three replications. ${ }^{*} p<0.05$, NS- not significant. 


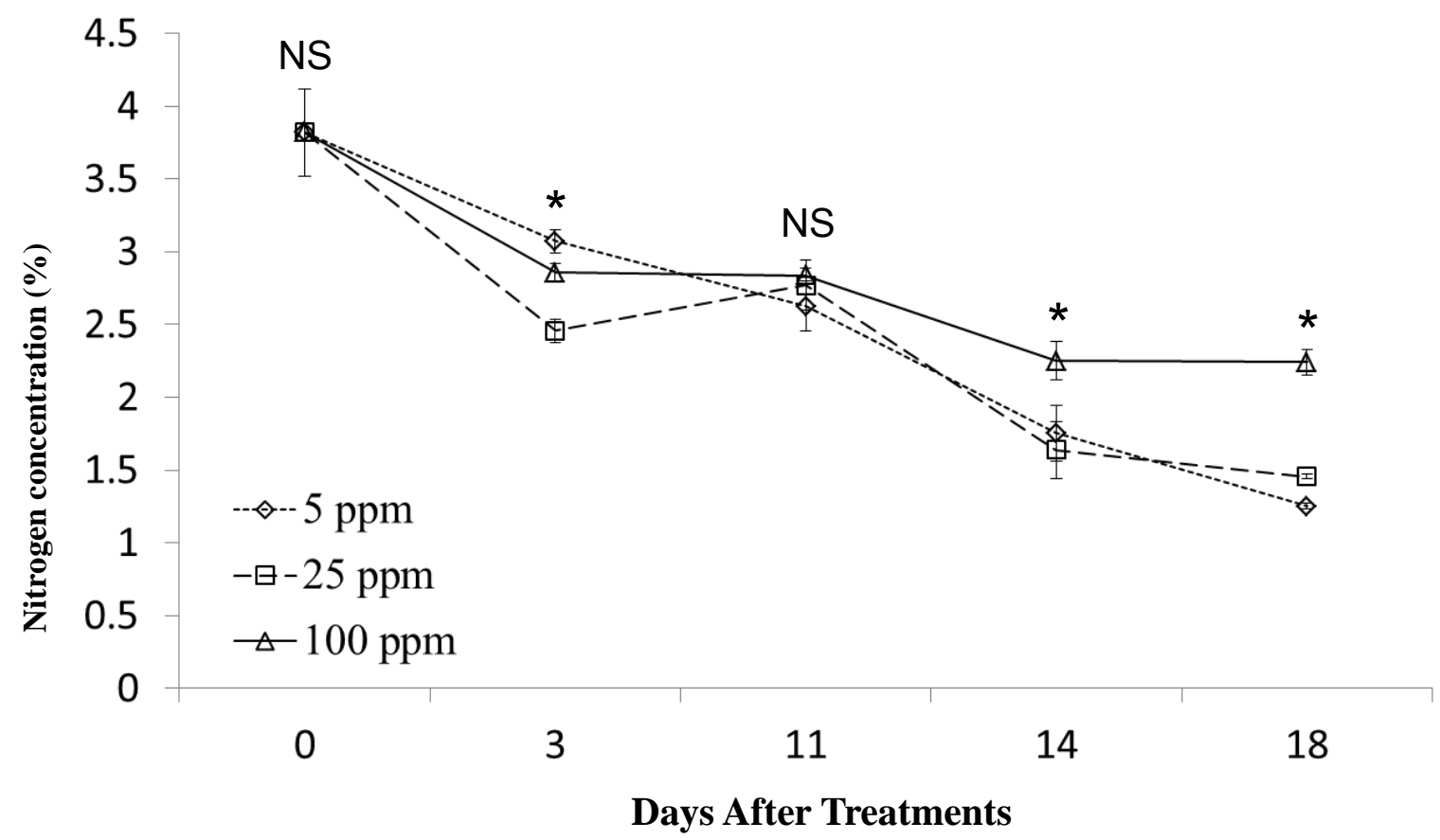

Fig. 7. Changes in leaf nitrogen concentration in Cowpea in 2016 with different treatments during reproductive growth. Bars indicate the standard deviations with three replications. $* p<0.05$, NS- not significant.

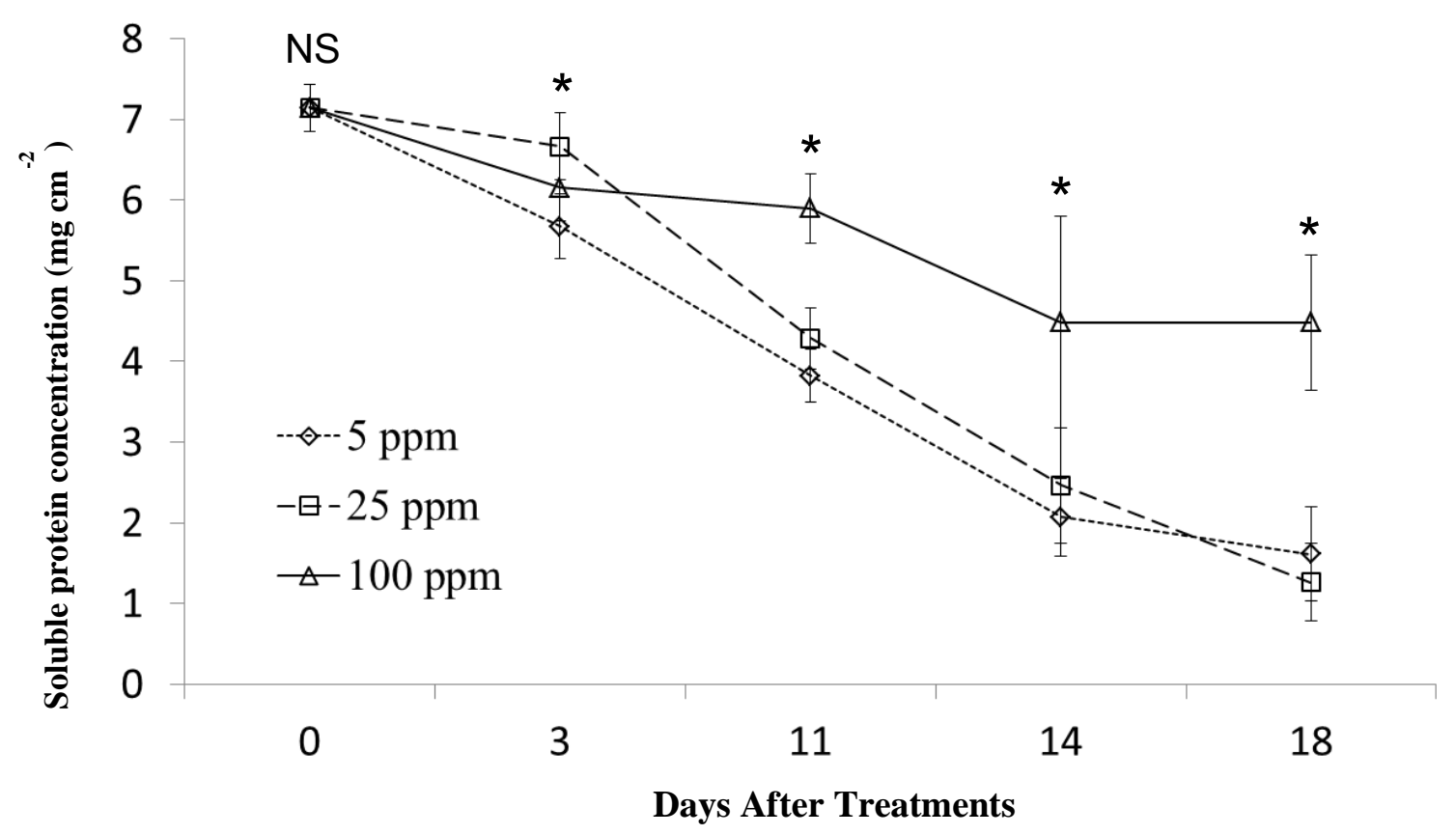

Fig. 8. Changes in soluble leaf protein concentration in Cowpea in 2016 with different treatments during reproductive growth. Bars indicate the standard deviations with three replications. $* p<0.05$, NS- not significant. 


\section{Discussion}

Even the leaves showed some senescent aspects, such as the decreases in SPAD value, nitrogen concentration, the leaves did not abscise and the plants kept green (Photo 1). It was also observed that the plants started to produce new pods after thatsenescent aspect. The reason behind this scenario might be the sufficient nitrogen accumulation is essential for second phase of pod setting. Plants provided with $100 \mathrm{ppm}$ of nitrogen can produce second phase of successful pods immediately. Second phase of pod setting was observed as a continuous process without any delay in this case. Plants with $100 \mathrm{ppm}$ nitrogen supply always remained green. After harvesting all matured pods in 5 and $25 \mathrm{ppm}$ nitrogen treatments, plants exposed to high nitrogen concentration (e.g., $400 \mathrm{ppm}$ ), started to produce inflorescence again and the leaves become green (data not shown). Pod and plant vigor was found higher in the plants treated with $100 \mathrm{ppm}$ nitrogen supply than that of 5 and $25 \mathrm{ppm}$.

On the other hand, cowpea plants supplied with low concentration of (5 and $25 \mathrm{ppm}$ ) of nitrogen couldn't produce second phase of successful pods. The reason behind this scenario might be the insufficient nitrogen hampered the second phase of pod setting. Plants provided with $100 \mathrm{ppm}$ of nitrogen didn't undergo leaf senescence. Pod setting was observed as a continuous process without any delay in this case. Plants with low concentration of nitrogen supply rendered the leaves to become yellow during pod development (Photo 2) in cowpea. After pod harvesting they become green again. Plants with $100 \mathrm{ppm}$ nitrogen supply always remained green. Pod and plant vigor was found higher in plants treated with $100 \mathrm{ppm}$ nitrogen supply than 5 and 25 ppm.

In contrast with these two leguminous crops, soybean plants open the flowers also for a long period, whereas the pods start growing almost at the same time and mature simultaneously (Zheng et al., 2003). It is widely understood that nitrogen accumulated in the vegetative organs before the initiation of seed filling provides the major source of seed nitrogen. Greater proportion (13.8 $37.9 \%$ ) of nitrogen in matured seeds comes from leaf tissues (Zhao et al. 2014a). The redistribution of nitrogen from the vegetative to the reproductive parts of soybean plants is considered to compensate the shortage of direct nitrogen assimilation by the root system during seed filling. The remobilization of stored nitrogen from leaves to the seeds is estimated at around R6 (full seed) stage when the direct assimilated nitrogen is not enough to fulfill the seed nitrogen demand (Islam et al., 2016). Since large amount of nitrogen in the vegetative organs is redistributed to the seeds, after the completion of seed filling, the soybean plant undergoes monocarpic senescence.
In mungbean and cowpea, flowering and fruiting concurrently occur over a long period. The pod growth starts immediately after the first flower opened, and matured even during flowering period. Some researchers (Brun and Betts, 1984; Baba et al., 2003) indicated that the pod growth does not begin immediately after flower open due to the competition for assimilate supply between reproductive and vegetative growth since the vegetative growth continues for a while even after the start of flowering in soybean. Another considerable reason might be the day length as the pod set is also affected by day length in soybean. In some cases if the day length is shortened the plant starts pod setting. A several studies documented that the pod growth was very slow after flowering in soybean. Zheng et al. (2003) found the lag period of pod growth was much longer in the flowers that opened early. Saitoh et al., (1998a) indicated that the rate of pod growth was slower in the low order raceme (early opening flowers) than that in the high order racemes (late opening flowers). These results suggest that the timing of pod formation play a role in the regulation of synchronous pod maturation in soybean. This synchronized pod maturation in soybean is immensely helpful for harvesting using combined harvester by the farmers. But for mungbean and cowpea, it is not possible to harvest by using harvester machines due to asynchronous pod maturation.

Furthermore, in soybean plants all of the leaves abscise and the stems become to be dead at the time when the pods matured. It is called monocarpic senescence or whole plant senescence, and makes the harvest work easy by machine. The understanding of their functions in soybean may be helpful to understand the mechanism of pod set, seed filling and yield. Improving mungbean and cowpea crop like soybean is very important to encourage the farmers to grow mungbean and cowpea in Southeast Asia.

The big difference of seed yield between soybean and mungbean is considered to be caused not by the biomass production but by the assimilate mobilization from vegetative organs to the seeds (harvest index). In soybean, it is well known that the plant still keeps the vegetative growth even after flower opening (Zheng et al., 2003). It makes the competition for assimilate between vegetative organs and reproductive sink, therefore, caused some flowers abortion. On the other hand, the pod growth in early flowers is slower than that of late flowers (Saitoh et al., 1998b; Zheng et al., 2003), indicating that a regulation system for the uniform pod growth and maturation exists in the plant. However, a little information is known about mungbean and cowpea. We attempted to find out the involvement of nitrogen nutrition in the process of occurrence of senescence in mungbean and cowpea. The presented data herewith, proved that nitrogen availability could affect the leaf senescence also in mungbean and cowpea; however, it could not trigger a monocarpic senescence like in 
soybean. Now, it might be of great interest to find out the genetic control of the monocarpic senescence in mungbean and cowpea.

The scenario of monocarpic senescence in soybean is not clear in mungbean and cowpea which do not show monocarpic senescence generally. Even the sign of leaf senescence (i.e., leaf yellowing) is observed in case of low nitrogen treatments, however, unlike with soybean, those crops do not show the characteristics of monocarpic senescence.

The reason for the difference in the response to nitrogen nutrition between soybean and other leguminous crops is not made clear in this study. One of the considerable reasons might be how does the sink (seed nitrogen accumulation) impact (or load) the source (nitrogen supply by whole plant) (Figs. 9 and 10). Soybean plants usually produce a huge number of fruits (pod, sink load) in a shorter duration of time, causing a shortage of nitrogen for seed filling. This nitrogen shortage induces the nitrogen remobilization from vegetative parts to the seeds, so thattriggers the monocarpic senescence. Against the soybean plants, in other legumes, such as mungbean and cowpea, smaller sink load (pod formation) is kept for a longer duration of time, resulting low or no remobilization of the nitrogen from vegetative parts to the seeds. As a result, no monocarpic senescence is observed in mungbean and cowpea.

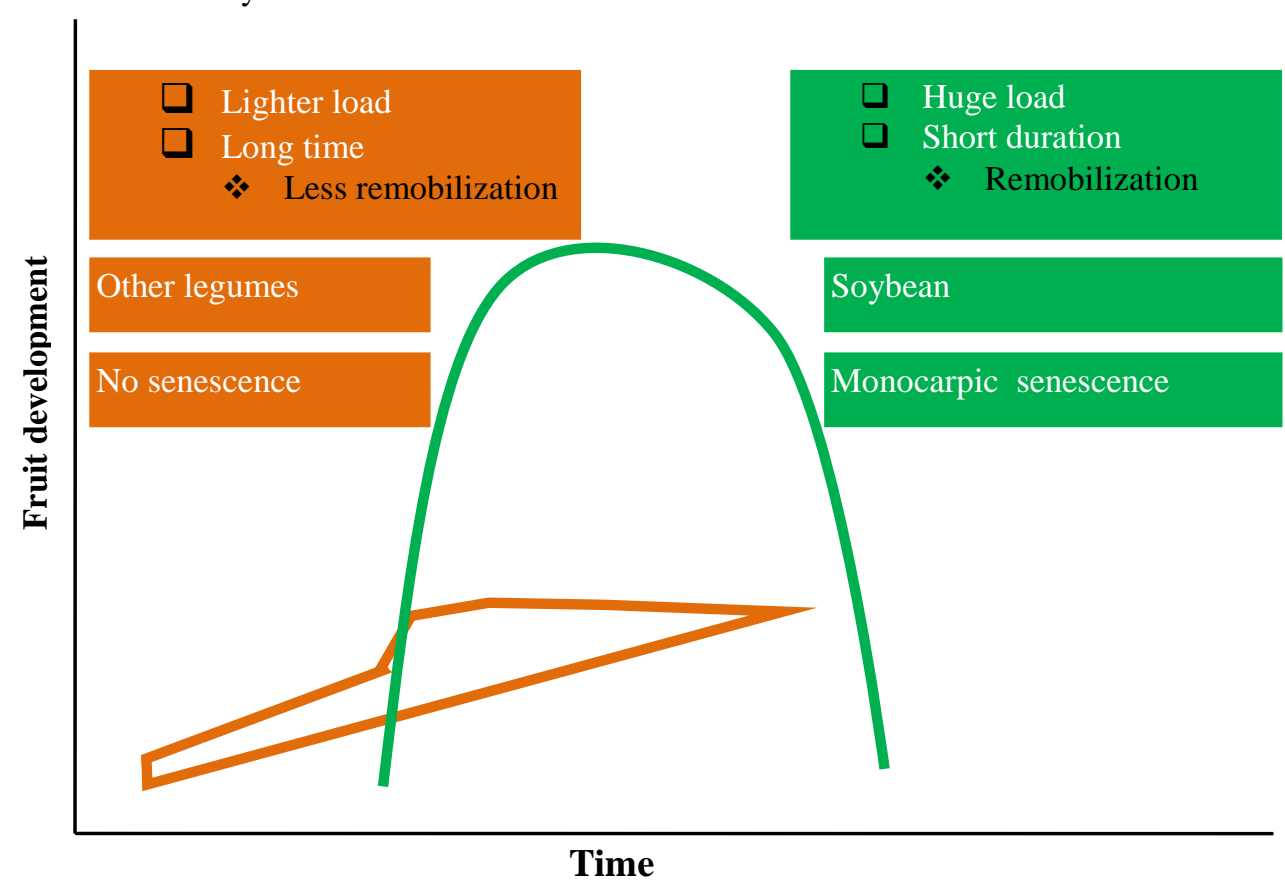

Fig. 9. Possible nitrogen remobilization sketch on the basis of sink load in bean plants during pod growth stage
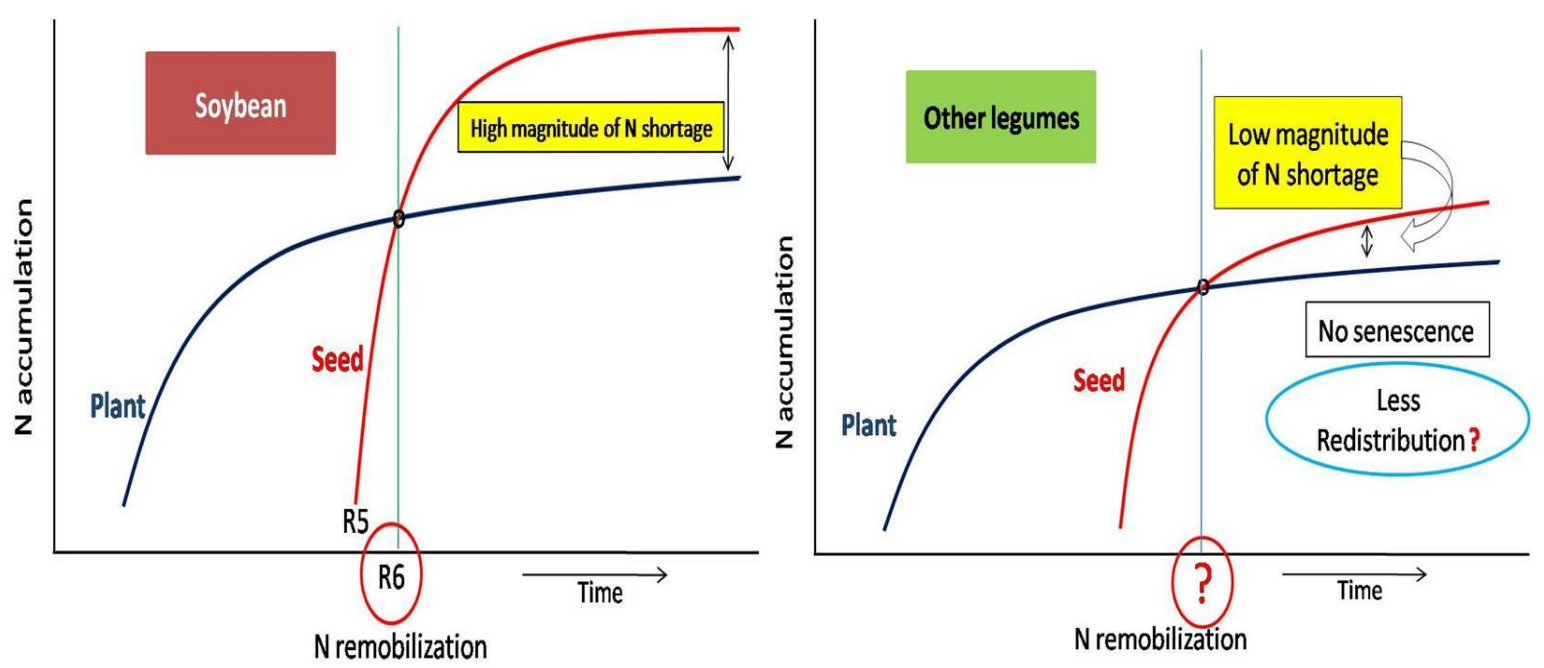

Fig. 10. Possible nitrogen remobilization sketch on the basis of nitrogen availability in bean plants during pod growth stage 
It is confirmed that the nitrogen supply controls the initiation and progress of monocarpic senescence in soybean (Islam et al., 2017). In mungbean and cowpea, even nitrogen manipulation express the influence on leaf senescence, however, whether the rate of seed nitrogen requirement exceeds the accumulation by mungbean and cowpea plants is yet to be investigated (Fig. 10).

\section{Acknowledgements}

The first author was awarded the Japanese Government Monbukagakusho Research Scholarship (2012) for conducting his $\mathrm{PhD}$ study in the United Graduate School of Agricultural Sciences, Kagoshima University (base: Saga University) Japan. This work was supported in part by a Grant-in-Aid from the Ministry of Education, Culture, Sports, Science and Technology of Japan (No. 25450024).

\section{References}

Baba, A., Zheng, S.-H., Matsunaga, R., Iwaya-Inoue, M., Furuya, T. and Fukuyama, M. 2003. Characteristics of dry matter production in Sachiyutaka a new soybean cultivar for southwest of Japan. Japanese Journal of Crop Science, 72: 384-389. https://doi.org/10.1626/ jes. 72.384

Bradford, M.M. 1976. A rapid and sensitive method for the quantitation of microgram quantities of protein utilizing the principle of protein-dye binding. Analytical Biochemistry, 72: 248-254. https://doi.org/10.1016/ 0003-2697(76)90527-3

Brun, W.A. and Betts, K.J. 1984. Source/Sink relations of abscising and non-abscising soybean flowers. Plant Physiology, 75:187-191. https://doi.org/10.1104/ pp.75.1.187 PMid:16663568 PMCid:PMC1066859

Islam, M.M. 2017. Studies on the function of nitrogen nutrition in monocarpic senescence in soybean (Glycine max (L.) Merrill). PhD Thesis, The United Graduate School of Agricultural Sciences, Kagoshima University, Japan. p. 45.

Islam, M.M., Ishibashi, Y., Nakagawa, A.C.S., Tomita, Y., Zhao, X., Inoue-Iwaya, M., Arima, S. and Zheng, S.-H. 2017. Nitrogen manipulation affects leaf senescence during late seed filling in soybean. Acta Physiologia Plantarum, 39: 42. https://doi.org/10.1007/s11738-0162334-0

Islam, M.M., Ishibashi, Y., Nakagawa, A.C.S., Tomita, Y., InoueIwaya, M., Arima, S. and Zheng, S.-H. 2016. Nitrogen redistribution and its relationship with the expression of
GmATG8c during seed filling in soybean. Journal of Plant Physiology, 192: 71-74. https://doi.org/10.1016/ j.jplph.2016.01.007 PMid:26871505

Jackson, M.L. 1973. Soil Chemical Analysis. Prentice Hall of India Pvt. Ltd., New Delhi. pp. 326-338.

Matsunaga, R., Matsumoto, S., Shimano, I. and Shimada, S. 1983. Varietal differences in nitrogen response of soybeans associated with their nodulation. Japanese Journal of Crop Science, 52: 423-429. https://doi.org/10.1626/ jcs. 52.423

Poehlman, J.M. 1991. The Mungbean. Westview Press, Oxford. pp. 1-5.

Rangel, A., Domont, G.B., Pedrosa, C. and Ferreira, S.T. 2003. Functional properties of purified vicilins from cowpea (Vignaunguiculata) and pea (Pisumsativum) and cowpea protein isolate. Journal of Agricultural and Food Chemistry, 51: 5792-5797. https://doi.org/ $\underline{10.1021 / \mathrm{jf0340052}}$ PMid: 12952435

Saitoh, K., Isobe, S. and Kuroda, T. 1998a. Differentiation and developmental stages of floral organs as influenced by nodal position on the stem and raceme order in a determinate type of soybean. Japanese Journal of Crop Science, 67: 85-91. https://doi.org/10.1626/jcs.67.523 https://doi.org/10.1626/jcs.67.85

Saitoh, K., Isobe, S. and Kuroda, T. 1998b. Pod elongation and seed growth as influenced by nodal position on stem and raceme order in a determinate type of soybean cultivars. Japanese Journal of Crop Science, 67: 523528. https://doi.org/10.1626/jcs.67.523 https://doi.org/10.1626/jcs.67.85

Tomooka, N., Lairungreeng, C., Nakeeraks, P., Egawa, Y. and Thavarasook, C. 1991. Production of mungbean and black gram. In: Mungbean and the Genetic Resources. TARC, Japan.

Zhao, X., Zheng, S.-H., Fatichin, Suzuki, A. and Arima, S. 2014a. Varietal difference in nitrogen redistribution from leaves and its contribution to seed yield in soybean. Plant Production Science,17: 103-108. https://doi.org/10.1626/pps.17.103

Zhao, X., Zheng, S.-H. and Arima, S. 2014b. Influence of nitrogen enrichment during reproductive growth stage on leaf nitrogen accumulation and seed yield in soybean. Plant Production Science,17: 209-217. https://doi.org/ 10.1626/pps.17.209

Zheng, S.-H., Maeda, A. and Fukuyama, M. 2003. Lag period of pod growth in soybean. Plant Production Science, 6:243-246. https://doi.org/10.1626/pps.6.243 